\title{
GSKB: A gene set database for pathway analysis in mouse
}

Liming Lai ${ }^{1}$, Jason Hennessey ${ }^{1}$, Valerie Bares ${ }^{1}$, Eun Woo Son ${ }^{1}$, Yuguang Ban ${ }^{1}$, Wei Wang ${ }^{1}$, Jianli Qi ${ }^{1}$, Gaixin Jiang ${ }^{1}$, Arthur Liberzon ${ }^{2}$, and Steven Xijin Ge ${ }^{1 *}$

${ }^{1}$ Department of Mathematics and Statistics, South Dakota State University, Brookings, SD 57007, USA

${ }^{2}$ Broad Institute of MIT and Harvard, 415 Main Street, Cambridge, MA 02142, USA

* Corresponding author: Tel: +1-605-688-5845; Email: gexijin@gmail.com

\section{ABSTRACT:}

Interpretation of high-throughput genomics data based on biological pathways constitutes a constant challenge, partly because of the lack of supporting pathway database. In this study, we created a functional genomics knowledgebase in mouse, which includes 33,261 pathways and gene sets compiled from 40 sources such as Gene Ontology, KEGG, GeneSetDB, PANTHER, microRNA and transcription factor target genes, etc. In addition, we also manually collected and curated 8,747 lists of differentially expressed genes from 2,526 published gene expression studies to enable the detection of similarity to previously reported gene expression signatures. These two types of data constitute a Gene Set Knowledgebase (GSKB), which can be readily used by various pathway analysis software such as gene set enrichment analysis (GSEA). Using our knowledgebase, we were able to detect the correct microRNA (miR-29) pathway that was suppressed using antisense oligonucleotides and confirmed its role in inhibiting fibrogenesis, which might involve upregulation of transcription factor SMAD3. The knowledgebase can be queried as a source of published gene lists for further meta-analysis. Through meta-analysis of 56 published gene lists related to retina cells, we revealed two fundamentally different types of gene expression changes. One is related to stress and inflammatory response blamed for causing blindness in many diseases; the other associated with visual perception by normal retina cells. GSKB is available online at http://ge-lab.org/gs/, and also as a Bioconductor package (gskb, https://bioconductor.org/packages/gskb/). This database enables in-depth interpretation of mouse genomics data both in terms of known pathways and the context of thousands of published expression signatures.

\section{INTRODUCTION}

Pathway analysis is a key step in analyzing high-throughput genomics data. The goal of pathway analysis is to determine if coherent change in gene expression occurs among a set of genes related to a molecular pathway or biological function. Many methods have been developed to achieve this goal (see review in [1]). While gene set enrichment analysis (GSEA) [2], one of the most popular programs, is based on nonparametric Kolmogorov-Smirnov statistic, several parametric algorithms have been developed [3, 4]. The foundation for all of these algorithms is a database of curated pathways and functional categories. The Molecular Signatures Database (MSigDB) [5] is a collection of gene lists initially developed for GSEA [2]. While its main focus is human, MSigDB also includes a small number of gene sets for mouse and rat. In addition to existing pathway databases, MSigDB also includes lists of differentially expressed genes manually collected from published gene expression studies related to genetic and chemical perturbations. Inclusion of these gene sets enables detection of the co-regulation of genes similar to those reported in the literature. The MSigDB has been widely used and greatly facilitate pathway analysis in human genomics studies.

As much of the work has been focused on gene sets in human, there is an urgent need of comprehensive pathway databases for other model organisms. Some researchers have to convert human genes into mouse 
orthologs in order to use MSigDB [6]. Other previous efforts include Genetrail [7], which constructs its own database by extracting information from several sources such as Gene Ontology [8], KEGG [9] etc. GeneSetDB is a larger collection of gene sets for several species based on 26 public databases [10]. Pathway and gene-set enrichment database(PAGED), which covers 20 species, derives information from many different sources including GeneSetDB and other disease-gene association data [11]. We recently created a pathway database for Arabidopsis [12].

In this study, we sought to develop a pathway knowledgebase for mouse, an important model organism for the study of many human diseases. We compiled gene sets from a large number of existing annotation databases as well as thousands of primary publications, which covers a wide spectrum of genetic, genomic and biological information. These gene sets forms a foundation for in-depth interpretation of mouse genomics data, supporting the use of mouse as a model for understanding human biology and diseases. We also demonstrate the use of this knowledgebase to generate testable hypotheses through several examples.

\section{METHODS}

Since most gene expression studies deposit gene expression data and publication information in public repositories, we first search for publications in Gene Expression Omnibus (GEO, www.ncbi.nlm.nih.gov/geo/) and ArrayExpress (www.ebi.ac.uk/arrayexpress/). We focused on mouse related expression studies in this study. Based on the information, the full text of the papers and their supplementary materials were retrieved. Then gene lists were compiled and curated after reading the papers and their supplementary materials. Similar to MSigDB [5] and AraPath [12], an unique identifier was assigned to each gene list. The names often start with the last names of the first authors and end with "_up", or "_down" to indicate whether the genes are up-regulated or down-regulated, respectively. A brief onesentence description was also given to each gene list. For example, gene list VENEZIA_FETALLIVER_UP represents genes highly expressed in fetal liver. A long description for the gene lists are abstracts of the paper from PubMed. We retrieved and processed all papers linked to GEO and ArrayExpress that we can found at the time of the study. We tried to collect all lists of differentially expressed genes reported in the literature. Larger lists (>3000 genes) are excluded. Finally, all gene lists were merged into an Excel spreadsheet to be further processed. One key step is the conversion of various gene IDs from different sources to NCBI gene symbols and Mouse Genome Informatics (MGI) IDs. The conversion was made based on the mouse genes information at NCBI, including platform definition files at GEO and other gene information files such as gene2accession.gz, Mm.data.gz, Mm.gb_cid_lid, and All_data.gene_info.gz (ftp://ftp.ncbi.nih.gov). Conversion to MGI IDs is carried out using information from MGI web site (www.informatics.jax.org). A Perl program was created to convert these gene IDs.

Gene lists from existing sources were manually imported in July 2013. Our web site (http://gskb.ge-lab.org) was assembled using a combination of the Python programming language, Django web framework, MySQL, JavaScript, and html. More detailed information about GSKB is included in supplementary file 3 which follows the BioDBcore guidelines [13]. This web site also includes data for other species such as the Arabidopsis gene sets [12], as well as other species that are still in the process.

Gene expression datasets were downloaded from GEO with accession numbers GSE40261and GSE27035. The raw Affymetrix .CEL files were processed using robust multiarray analysis (RMA) algorithm [14] as implemented in Bioconductor [15]. "Present" or "Absent" calls were calculated using the Affymetrix MAS5 algorithm based on Wilcoxon Rank Sum test. Probe-sets with "Absent" calls across all samples were deemed not significantly above background and removed from further analysis. Probe-set IDs were mapped to official gene symbol based on the mapping in Bioconductor package mouse4302.db. If multiple probe-sets were mapped to the same gene, we retained the one with the largest standard deviation. The 
processed gene expression data is available as supplementary file 4. GSEA version 2.0 was used with default parameters to analyze GSE40261. We also used another method, parametric analysis of gene set enrichment (PAGE) [3], implemented in the PGSEA package [16]. Gene expression data was meancentered before using PGSEA, which calculates a $t$-statistic for each gene-set in every sample to measure whether the genes are collectively up- or down-regulated. The $t$-statistics were used in an analysis of variance (ANOVA) to test whether there is significant difference between sample groups. Gene sets are ranked by the difference in average $t$-statistic.

\section{RESULTS AND DISCUSSION}

GSKB is a comprehensive knowledgebase for pathway analysis in mouse. It complements MSigDB, which contains a small number of mouse gene lists. Unlike GeneSetDB [10], GSKB includes a large number of lists of differentially expressed genes. The data can be downloaded and used by various software packages for pathway analysis. Our web site also includes an interface for keyword search. The keywords can be a topic-related ("stem cell"), or a gene symbol ("SOX2"), which will be compared against all the descriptions including the abstracts as well as gene lists. In addition, we also provide a similarity search page, where users can upload a gene list, and our web server will compare user's gene lists with all the gene lists in the database and return those that have statistically significant overlaps.

\section{Construction of the knowledgebase}

As a first step, we gathered annotation information from 40 existing databases for mouse-related gene sets (Table 1). These gene sets are divided into 8 categories, namely, Co-expression, Gene Ontology, Curated pathways, Metabolic Pathways, Transcription Factor (TF) and microRNA target genes, location (cytogenetics band), and others. We used information in GeneSetDB [10] for some of the databases. Detailed information on these 40 sources and the citations is available in supplementary file 1.

The gene lists from literature were retrieved manually from individual gene expression studies through a process similar to the one used to create AraPath, a similar resource for Arabidopsis[12]. As most expression studies upload raw data to repositories like GEO and ArrayExpress, we used the meta-data in these databases to search for publications. We scanned all datasets we can found and retrieved 4,313 potentially useful papers reporting gene expression studies in mouse. These papers were individually read by curators to identify lists of differentially expressed genes in various conditions. We compiled a total of 8,747 lists of differently expressed genes from 2,518 of papers (See supplementary information 2 for citations). Each gene list was annotated with a unique name, brief description, and publication information, similar to the protocol used in MSigDB and Arapath [12]. These gene lists constitute a large collection of published expression signatures that form a foundation for interpret new gene lists and expression profiles.

These 8,747 gene lists collected from literature include a total of 29,876 unique gene symbols. Interestingly, the distribution of the sizes of published gene lists approximates a normal distribution on logarithm scale (Fig. 1). Although the median size is 51 , there are many gene lists containing a few hundreds of genes. The most frequently appeared genes in these lists are shown in Table 2. It includes genes related to cell cycle (CCND2, CDKN1A), and immune response (SOCS3, FOS). Many were intensively-studied, as suggested by the number of related PubMed hits when using gene symbol in keyword searches.

\section{Using the database}

The database can be downloaded at our web site (http://ge-lab.org/gs/), and used with various pathway analysis software. The web site can also be searched using keywords representing either gene names or pathway names. Using the "Find related genesets" page, users can also upload their own lists of genes and 
search the database for gene sets with significant overlap. Finally, we also created a Bioconductor package "gskb" (https://bioconductor.org/packages/gskb/) that provide access to this data.

\section{In-depth analysis of the expression profile of miR-29 silencing and induction}

To test if known pathways could be detected, we re-analyzed a gene expression dataset from Hand et al. [17], which is available in GEO database with accession number GSE40261. In this experiment, mice were injected of antisense oligonucleotides against miR-29a or a scrambled sequence as control. The antisense oligonucleotides should suppress the expression of miR-29a, thereby affect the expression of the set of genes inhibited by this microRNA in liver tissue. We downloaded and processed the raw Affymetrix files and used different pathway analysis software to detect significantly altered pathways (See Methods for details). We first focused on 1869 predicted microRNA target gene sets. Table 3 shows the top gene sets using GSEA. It is clear that the most significantly affected pathways are those related to miR-29a, b, and c. We also used another method, parametric analysis of gene set enrichment (PAGE) [3], as implemented in the PGSEA package [16]. The results are shown in Fig. 2. The top 6 pathways are all miR-29 target gene sets. Therefore, the expected molecular pathway was detected using different software.

To gain further insight into the downstream molecular pathways, we analyze this expression data using other gene sets in GSKB. Using the PGSEA software, we identified significantly altered pathways in many different types of gene sets. Table 4 shows some of the top ranked gene sets by category. In the coexpression category, we detected that the change in expression profile when miR-29c was suppressed are similar to several reported expression signatures. The top 5 signatures are related to various perturbations of liver cells such as overexpression of TCFAP2C [18], or treatment with rosiglitazone [19], a compound that can lower glucose levels. The third most significantly gene set (Nones_Mdr1A_CurcuminDiet_Fibrogenesis_Dn) includes genes involved in fibrogenesis down-regulated in the colon of multidrug resistance gene-deficient (mdr1a-/-) mice fed with curcumin diet [20]. Fibrogenesis is a process regulating the deposition of extracellular matrix proteins. This is in fact a reoccurring theme in multiple significant gene sets across categories. For example, two significant Gene Ontology terms are "Extracellular Matrix Structural Constituent", and "Collagen Fibril Organization". Other related gene sets are "ECM-Receptor Interaction", "Integrin", and "Beta Integrin Cell Surface Interactions". These results strongly suggest that lower expression of miR-29 caused by antisense oligonucleotides leads to the up-regulation of extracellular matrix proteins and fibrogenesis in hepatic cells. This agrees with the well-established role of miR-29 in fibrosis in liver [21], and several other tissues/cells such as heart [22], stellate cells [23] and HK-2 cells (human kidney cell line) [24] etc. All members of the miR-29 family were found to be downregulated in murine livers treated with carbon tetrachloride to induce hepatic fibrogenesis [21]. Roderburg et al. [21] also noted abnormally low expression of miR-29 in patients with advanced liver fibrosis and liver cirrhosis. Thus GSKB enables us to identify downstream molecular pathways regulated by the miR-29 family.

Table 4 also shows transcription factors that might be involved. Treatment with anti-miR-29 oligonucleotides is associated with reduced expression of Srebfl (sterol regulatory element binding transcription factor 1) target genes. Srebfl is regulator of lipid homeostatsis [25] and directly binds to sterol regulatory element-1 (SRE1) flanking LDL receptor genes and other related genes. This suggests that lower expression of miR-29 might hinder the normal function of hepatic cells in metabolism. Therefore high expression of miR-29 expression in hepatic cells is required for lipid metabolism and that Srebf1 might be downstream of miR-29. There does not appear to be any existing evidence linking miR-29 with Srebfl. This is a directly testable hypothesis for further experimental studies regarding the function of miR29.

Table 4 also indicates that anti-miR-29 treatment lead to increased expression of Smad3 (SMAD family member 3 ) target genes. It is well-established that Smad3 is a key player in TGF $\beta$-mediated fibrosis, 
tumor suppression and metastasis [26]. Qin et al. provided evidence that Smad3-mediated suppression of miR-29 expression by $T G F \beta 1$ is achieved by direct binding to the promoter of miR-29 [27], and overexpression of miR-29b inhibits the collagen I and III and prevents renal fibrosis. In our analysis, suppression of miR-29 leads to the upregulation of Smad3 target genes, suggesting that Smad3 and miR-29 might form a negative regulation loop. Indeed, Xiao et al. [28] provided some evidence that gene transfer of miR-29 was able to block bleomycin-induced pulmonary fibrosis by suppressing the expression of TGF $\beta$-1and inhibiting Smad3 phosphorylation.

To further confirm these findings, we analyzed another expression data set (GSE27035), in which fetal astrocytes were transfected with miR-29 [29]. We obtained similar results (data not shown) regarding the extracellular matrix related gene sets. For transcriptional factors, E2F family members are highly significant, which is not observed in hepatic cells in the previous dataset. But Smad3 targets genes are downregulated, suggesting that the universal regulation of extracellular matrix genes by miR-29 might be related to $\mathrm{Smad} 3$.

\section{Identifying transcription factors from gene expression data}

In another example, we used our knowledgebase to detect transcription factors (TFs) responsible for tissuespecific gene expression. We analyzed a large gene expression dataset consisting of 3 or 4 biological replicates for each of the 24 mouse tissues [30] (NCBI accession number GSE24207). We used a subset of 373 predicted TF target gene sets in our analysis using PGSEA. Fig. 2 lists top 30 most significant TFs associated with various tissues. Many highly significant TFs are known to be involved in different organs. The most significant are the hepatocyte nuclear factors (HNF4A, HNF1A, and FOXA2/HNF3B) that are highly expressed in the liver and are supported by many studies to be involved in liver development [31]. The target genes of SPI1 (Spleen focus forming virus proviral integration oncogene, also listed as SFPI1) are highly expressed in spleen and bone marrow, in agreement with the fact that SPI1 is an ETS-domain transcription factor involved in myeloid and B-lymphoid cell development [32]. Another very highly significant TF, Steroidogenic Factor-1 (NR5A1), is found to be responsible for adrenal gland-specific expression profile. This nuclear receptor is known to play an important role in adrenal development and function and mutations in this protein are associated with adrenal hypolasia [33]. PPARG (peroxisome proliferator activated receptor gamma) is essential for the differentiation of adipose tissue [34]. In our result, its target genes were found to be significant highly expressed in the adipose tissue. Most of the TFs in Fig. 2 are supported by previous studies in the literature.

\section{Meta-analysis of published gene lists yields insight into blindness and visual perception}

The comprehensive dataset can also serve as an information source on published expression signatures. For example, using a keyword "retina" to conduct a search at our web site, we retrieved 56 published signatures from 26 genome-wide expression studies of the retina cells. Detailed information on each of gene lists, including links to PubMed, is available for further examination.

Meta-analysis of a set of retrieved signatures can provide insights into the relationship among multiple previously published expression profiles. We conducted an all-versus-all overlapping analysis of these 56 gene lists. Following the method developed previously [35], we generated a network where nodes correspond to gene lists and edges represent significant overlaps between them (Fig.4). We found 52 significant overlaps (FDR $<0.0001)$ among 25 gene lists. Interestingly, the overlaps define two groups with high similarity within each group and very little in between. Group A on the left side of Fig. 4 includes gene lists that are upregulated in ageing, bright-light-damaged retina, or other injury, as well as hypoxia treatment from 3 independent studies[36-38]. Retinal hypoxia is believed to be the mechanism of blinding 
underlying several diseases [39] and have been subjected to studies using animal models. Our results suggest that there is significant similarity in gene expression response across multiple studies. We identified the most frequently shared genes across these 10 gene lists in group A. Table 5 lists 29 genes that are shared by 3 or more gene lists in group A gene lists. These 29 genes are significantly enriched in genes related to inflammatory response ( $\mathrm{P}$ value $<1.80 \mathrm{E}-05)$, and immune response ( $\mathrm{P}$ value $<5.30 \mathrm{E}-03)$. This is in agreement with previous finding regarding the activation of inflammatory response upon hypoxia treatment [39]. As shown in Table 5, the most commonly upregulated genes in group A is the glial fibrillary acidic protein (GFAP), which was initially discovered as an indicator of stress in astrocytes in the brain, but its activation in the radial glia (Müller cells) is also known to signal stress in the retina [40]. Based on the consensus of 8 genome-wide expression studies, our new gene lists in Table 5 thus could serve as marker for stress response in the retina caused by hypoxia or other injuries.

On the other hand, the 15 gene lists in group B on the right side of Fig. 4 have different biological theme. Three of the gene lists (ZHANG_RETINAL-EXPLANT_RB1_DN, COTTET_RPE65_RETINA_DN, DEL-TORO_EC-DLL4_RETINAS_-̄N) are genes downregulated in retina with mutated genes (Rb1[41], RPE65[42], and DLL4[43]), compared with normal retina. Another gene list includes genes downregualted in hypoxic retina [36]. This seems to suggest that gene lists in this group might include genes specifically required for normal photoreceptive function of the retina cells. This is confirmed by examining the frequently appearing genes in this group. Among the 38 genes (Table 6) that are shared by 3 or more lists in this group, half of them are related to visual perception according to GO, which is extremely significant $(\mathrm{P}<1.2 \mathrm{E}-28)$. The most frequently appearing gene ARR3 (arrestin 3, retinal) are predicted to play an important role in retina-specific signal transduction with possible binding to photoactivated-phosphorylated opsins, including OPN1SW (opsin 1) that are shared by 7 of the 15 gene lists (Table 6). Based on multiple studies, table 6 serves as a reliable list of retina-specific genes important for photoreception.

Overall, through meta-analysis of 56 retina-related gene lists, we revealed two fundamentally different types of gene expression changes in the retina. One is related to stress response and inflammatory response that are blamed for blindness in many diseases; the other is a set of genes that are required by visual perception by the retina cells. Our database could be used to conduct similar meta-analysis using various search keywords.

\section{CONCLUSION}

We have created a comprehensive gene set database for pathway analysis in mouse. We also demonstrated that this database could be used with different pathway analysis software to gain insights into genome-wide expression profiles. For further improvement of knowledgebase, we will update the database from existing sources, and also continue to improve the accuracy of the existing curation, and search for additional published gene lists.

\section{FUNDING}

This work was supported in part by the National Institutes of Health (R01GM083226 and R01CA121941). This material is based upon work supported partially by the National Science Foundation/EPSCoR Award No. IIA-1355423 and by the state of South Dakota.

\section{ACKNOWLEDGEMENTS}

The authors thank Drs. Jill Mesirov and Arthur Liberzon for advices on gene list collection, and the reviewers for many constructive suggestions 
Conflict of Interest: None declared.

1. Huang da W, Sherman BT, Lempicki RA: Bioinformatics enrichment tools: paths toward the comprehensive functional analysis of large gene lists. Nucleic Acids Res 2009, 37:1-13.

2. Subramanian A, Tamayo P, Mootha VK, Mukherjee S, Ebert BL, Gillette MA, Paulovich A, Pomeroy SL, Golub TR, Lander ES, Mesirov JP: Gene set enrichment analysis: a knowledge-based approach for interpreting genome-wide expression profiles. Proc Natl Acad Sci U S A 2005, 102:15545-15550.

3. Kim SY, Volsky DJ: PAGE: parametric analysis of gene set enrichment. BMC Bioinformatics 2005, 6:144.

4. Irizarry RA, Wang C, Zhou Y, Speed TP: Gene set enrichment analysis made simple. Stat Methods Med Res 2009, 18:565-575.

5. Liberzon A, Subramanian A, Pinchback R, Thorvaldsdottir H, Tamayo P, Mesirov JP: Molecular signatures database (MSigDB) 3.0. Bioinformatics 2011, 27:1739-1740.

6. Ellis J, Goodswen S, Kennedy PJ, Bush S: The core mouse response to infection by neospora caninum defined by gene set enrichment analyses. Bioinform Biol Insights 2012, 6:187-202.

7. Backes C, Keller A, Kuentzer J, Kneissl B, Comtesse N, Elnakady YA, Muller R, Meese E, Lenhof HP: GeneTrail--advanced gene set enrichment analysis. Nucleic Acids Res 2007, 35:W186-192.

8. Ashburner M, Ball CA, Blake JA, Botstein D, Butler H, Cherry JM, Davis AP, Dolinski K, Dwight SS, Eppig JT, et al: Gene ontology: tool for the unification of biology. The Gene Ontology Consortium. Nat Genet 2000, 25:25-29.

9. Kanehisa M, Goto S, Hattori M, Aoki-Kinoshita KF, Itoh M, Kawashima S, Katayama T, Araki M, Hirakawa M: From genomics to chemical genomics: new developments in KEGG. Nucleic Acids Res 2006, 34:D354-357.

10. Araki H, Knapp C, Tsai P, Print C: GeneSetDB: A comprehensive meta-database, statistical and visualisation framework for gene set analysis. FEBS Open Bio 2012, 2:76-82.

11. Huang H, Wu X, Sonachalam M, Mandape SN, Pandey R, MacDorman KF, Wan P, Chen JY: PAGED: a pathway and gene-set enrichment database to enable molecular phenotype discoveries. $B M C$ Bioinformatics 2012, 13 Suppl 15:S2.

12. Lai L, Liberzon A, Hennessey J, Jiang G, Qi J, Mesirov JP, Ge SX: AraPath: a knowledgebase for pathway analysis in Arabidopsis. Bioinformatics 2012, 28:2291-2292.

13. Gaudet P, Bairoch A, Field D, Sansone SA, Taylor C, Attwood TK, Bateman A, Blake JA, Bult CJ, Cherry JM, et al: Towards BioDBcore: a community-defined information specification for biological databases. Database (Oxford) 2011, 2011:baq027.

14. Irizarry RA, Hobbs B, Collin F, Beazer-Barclay YD, Antonellis KJ, Scherf U, Speed TP: Exploration, normalization, and summaries of high density oligonucleotide array probe level data. Biostatistics 2003, 4:249-264.

15. Gentleman RC, Carey VJ, Bates DM, Bolstad B, Dettling M, Dudoit S, Ellis B, Gautier L, Ge Y, Gentry $\mathrm{J}$, et al: Bioconductor: open software development for computational biology and bioinformatics. Genome Biol 2004, 5:R80.

16. Furge K, Dykema K: PGSEA: Parametric Gene Set Enrichment Analysis. $R$ package version 1360 2012.

17. Hand NJ, Horner AM, Master ZR, Boateng LA, LeGuen C, Uvaydova M, Friedman JR: MicroRNA profiling identifies miR-29 as a regulator of disease-associated pathways in experimental biliary atresia. J Pediatr Gastroenterol Nutr 2012, 54:186-192.

18. Holl D, Kuckenberg P, Woynecki T, Egert A, Becker A, Huss S, Stabenow D, Zimmer A, Knolle P, Tolba R, et al: Transgenic overexpression of Tcfap2c/AP-2gamma results in liver failure and intestinal dysplasia. PLoS One 2011, 6:e22034.

19. Wang P, Renes J, Bouwman F, Bunschoten A, Mariman E, Keijer J: Absence of an adipogenic effect of rosiglitazone on mature 3T3-L1 adipocytes: increase of lipid catabolism and reduction of adipokine expression. Diabetologia 2007, 50:654-665. 
20. Nones K, Dommels YE, Martell S, Butts C, McNabb WC, Park ZA, Zhu S, Hedderley D, Barnett MP, Roy NC: The effects of dietary curcumin and rutin on colonic inflammation and gene expression in multidrug resistance gene-deficient (mdr1a-/-) mice, a model of inflammatory bowel diseases. Br J Nutr 2009, 101:169-181.

21. Roderburg C, Urban GW, Bettermann K, Vucur M, Zimmermann H, Schmidt S, Janssen J, Koppe C, Knolle $\mathrm{P}$, Castoldi $\mathrm{M}$, et al: Micro-RNA profiling reveals a role for miR-29 in human and murine liver fibrosis. Hepatology 2011, 53:209-218.

22. van Rooij E, Sutherland LB, Thatcher JE, DiMaio JM, Naseem RH, Marshall WS, Hill JA, Olson EN: Dysregulation of microRNAs after myocardial infarction reveals a role of miR-29 in cardiac fibrosis. Proc Natl Acad Sci U S A 2008, 105:13027-13032.

23. Ogawa T, Iizuka M, Sekiya Y, Yoshizato K, Ikeda K, Kawada N: Suppression of type I collagen production by microRNA-29b in cultured human stellate cells. Biochem Biophys Res Commun 2010, 391:316-321.

24. Du B, Ma LM, Huang MB, Zhou H, Huang HL, Shao P, Chen YQ, Qu LH: High glucose downregulates miR-29a to increase collagen IV production in HK-2 cells. FEBS Lett 2010, 584:811-816.

25. Yokoyama C, Wang X, Briggs MR, Admon A, Wu J, Hua X, Goldstein JL, Brown MS: SREBP-1, a basic-helix-loop-helix-leucine zipper protein that controls transcription of the low density lipoprotein receptor gene. Cell 1993, 75:187-197.

26. Roberts AB, Tian F, Byfield SD, Stuelten C, Ooshima A, Saika S, Flanders KC: Smad3 is key to TGFbeta-mediated epithelial-to-mesenchymal transition, fibrosis, tumor suppression and metastasis. Cytokine Growth Factor Rev 2006, 17:19-27.

27. Qin W, Chung AC, Huang XR, Meng XM, Hui DS, Yu CM, Sung JJ, Lan HY: TGF-beta/Smad3 signaling promotes renal fibrosis by inhibiting miR-29. J Am Soc Nephrol 2011, 22:1462-1474.

28. Xiao J, Meng XM, Huang XR, Chung AC, Feng YL, Hui DS, Yu CM, Sung JJ, Lan HY: miR-29 inhibits bleomycin-induced pulmonary fibrosis in mice. Mol Ther 2012, 20:1251-1260.

29. Tanabe H, Kohno N, Yamaguchi M: Global profiling of gene expression in mouse astrocyte in response to the potential longevity determinant miR-29. Mem Fac Agr Kinki Univ 2012, 45:1-16.

30. Thorrez L, Laudadio I, Van Deun K, Quintens R, Hendrickx N, Granvik M, Lemaire K, Schraenen A, Van Lommel L, Lehnert S, et al: Tissue-specific disallowance of housekeeping genes: the other face of cell differentiation. Genome Res 2011, 21:95-105.

31. Parviz F, Matullo C, Garrison WD, Savatski L, Adamson JW, Ning G, Kaestner KH, Rossi JM, Zaret KS, Duncan SA: Hepatocyte nuclear factor 4alpha controls the development of a hepatic epithelium and liver morphogenesis. Nat Genet 2003, 34:292-296.

32. Moreau-Gachelin F, Tavitian A, Tambourin P: Spi-1 is a putative oncogene in virally induced murine erythroleukaemias. Nature 1988, 331:277-280.

33. Phelan JK, McCabe ER: Mutations in NR0B1 (DAX1) and NR5A1 (SF1) responsible for adrenal hypoplasia congenita. Hum Mutat 2001, 18:472-487.

34. Rosen ED, Sarraf P, Troy AE, Bradwin G, Moore K, Milstone DS, Spiegelman BM, Mortensen RM: PPAR gamma is required for the differentiation of adipose tissue in vivo and in vitro. Mol Cell 1999, 4:611-617.

35. Ge SX: Large-scale analysis of expression signatures reveals hidden links among diverse cellular processes. BMC Syst Biol 2011, 5:87.

36. Ishikawa K, Yoshida S, Kadota K, Nakamura T, Niiro H, Arakawa S, Yoshida A, Akashi K, Ishibashi $\mathrm{T}$ : Gene expression profile of hyperoxic and hypoxic retinas in a mouse model of oxygen-induced retinopathy. Invest Ophthalmol Vis Sci 2010, 51:4307-4319.

37. Rattner A, Nathans J: The genomic response to retinal disease and injury: evidence for endothelin signaling from photoreceptors to glia. $J$ Neurosci 2005, 25:4540-4549.

38. Zhu Y, Natoli R, Valter K, Stone J: Differential gene expression in mouse retina related to regional differences in vulnerability to hyperoxia. Mol Vis 2010, 16:740-755.

39. Kaur C, Foulds WS, Ling EA: Hypoxia-ischemia and retinal ganglion cell damage. Clin Ophthalmol 2008, 2:879-889. 
40. Lewis GP, Fisher SK: Up-regulation of glial fibrillary acidic protein in response to retinal injury: its potential role in glial remodeling and a comparison to vimentin expression. Int Rev Cytol 2003, 230:263-290.

41. Zhang J, Gray J, Wu L, Leone G, Rowan S, Cepko CL, Zhu X, Craft CM, Dyer MA: Rb regulates proliferation and rod photoreceptor development in the mouse retina. Nat Genet 2004, 36:351-360.

42. Cottet S, Michaut L, Boisset G, Schlecht U, Gehring W, Schorderet DF: Biological characterization of gene response in Rpe65-/- mouse model of Leber's congenital amaurosis during progression of the disease. FASEB J 2006, 20:2036-2049.

43. del Toro R, Prahst C, Mathivet T, Siegfried G, Kaminker JS, Larrivee B, Breant C, Duarte A, Takakura $\mathrm{N}$, Fukamizu A, et al: Identification and functional analysis of endothelial tip cell-enriched genes. Blood 2010, 116:4025-4033.

44. Newman JC, Weiner AM: L2L: a simple tool for discovering the hidden significance in microarray expression data. Genome Biol 2005, 6:R81.

45. Higgins ME, Claremont M, Major JE, Sander C, Lash AE: CancerGenes: a gene selection resource for cancer genome projects. Nucleic Acids Res 2007, 35:D721-726.

46. Culhane AC, Schroder MS, Sultana R, Picard SC, Martinelli EN, Kelly C, Haibe-Kains B, Kapushesky M, St Pierre AA, Flahive W, et al: GeneSigDB: a manually curated database and resource for analysis of gene expression signatures. Nucleic Acids Res 2012, 40:D1060-1066.

47. Ashburner M, Ball CA, Blake JA, Botstein D, Butler H, Cherry JM, Davis AP, Dolinski K, Dwight SS, Eppig JT, et al: Gene Ontology: tool for the unification of biology. Nature Genetics 2000, 25:25-29.

48. Mi H, Lazareva-Ulitsky B, Loo R, Kejariwal A, Vandergriff J, Rabkin S, Guo N, Muruganujan A, Doremieux $\mathrm{O}$, Campbell MJ, et al: The PANTHER database of protein families, subfamilies, functions and pathways. Nucleic Acids Res 2005, 33:D284-288.

49. Kelder T, van Iersel MP, Hanspers K, Kutmon M, Conklin BR, Evelo CT, Pico AR: WikiPathways: building research communities on biological pathways. Nucleic Acids Res 2012, 40:D1301-1307.

50. Yamamoto S, Sakai N, Nakamura H, Fukagawa H, Fukuda K, Takagi T: INOH: ontology-based highly structured database of signal transduction pathways. Database (Oxford) 2011, 2011:bar052.

51. Kandasamy K, Mohan SS, Raju R, Keerthikumar S, Kumar GS, Venugopal AK, Telikicherla D, Navarro JD, Mathivanan S, Pecquet $\mathrm{C}$, et al: NetPath: a public resource of curated signal transduction pathways. Genome Biol 2010, 11:R3.

52. Jupe S, Akkerman JW, Soranzo N, Ouwehand WH: Reactome - a curated knowledgebase of biological pathways: megakaryocytes and platelets. $J$ Thromb Haemost 2012.

53. Kanehisa M, Goto S, Hattori M, Aoki-Kinoshita KF, Itoh M, Kawashima S, Katayama T, Araki M, Hirakawa M: From genomics to chemical genomics: new developments in KEGG. Nucleic Acids Research 2006, 34:D354-D357.

54. Ma H, Sorokin A, Mazein A, Selkov A, Selkov E, Demin O, Goryanin I: The Edinburgh human metabolic network reconstruction and its functional analysis. Mol Syst Biol 2007, 3:135.

55. Evsikov AV, Dolan ME, Genrich MP, Patek E, Bult CJ: MouseCyc: a curated biochemical pathways database for the laboratory mouse. Genome Biol 2009, 10:R84.

56. Mattingly CJ, Rosenstein MC, Colby GT, Forrest JN, Jr., Boyer JL: The Comparative Toxicogenomics Database (CTD): a resource for comparative toxicological studies. $J$ Exp Zool $A$ Comp Exp Biol 2006, 305:689-692.

57. Kuhn M, Campillos M, Letunic I, Jensen LJ, Bork P: A side effect resource to capture phenotypic effects of drugs. Mol Syst Biol 2010, 6:343.

58. Gunther S, Kuhn M, Dunkel M, Campillos M, Senger C, Petsalaki E, Ahmed J, Urdiales EG, Gewiess A, Jensen LJ, et al: SuperTarget and Matador: resources for exploring drug-target relationships. Nucleic Acids Res 2008, 36:D919-922.

59. Wishart DS, Knox C, Guo AC, Cheng D, Shrivastava S, Tzur D, Gautam B, Hassanali M: DrugBank: a knowledgebase for drugs, drug actions and drug targets. Nucleic Acids Res 2008, 36:D901-906.

60. Frolkis A, Knox C, Lim E, Jewison T, Law V, Hau DD, Liu P, Gautam B, Ly S, Guo AC, et al: SMPDB: The Small Molecule Pathway Database. Nucleic Acids Res 2010, 38:D480-487. 
61. Wang X: miRDB: a microRNA target prediction and functional annotation database with a wiki interface. $R N A$ 2008, 14:1012-1017.

62. Betel D, Wilson M, Gabow A, Marks DS, Sander C: The microRNA.org resource: targets and expression. Nucleic Acids Res 2008, 36:D149-153.

63. Grimson A, Farh KK, Johnston WK, Garrett-Engele P, Lim LP, Bartel DP: MicroRNA targeting specificity in mammals: determinants beyond seed pairing. Mol Cell 2007, 27:91-105.

64. Vergoulis T, Vlachos IS, Alexiou P, Georgakilas G, Maragkakis M, Reczko M, Gerangelos S, Koziris $\mathrm{N}$, Dalamagas $\mathrm{T}$, Hatzigeorgiou AG: TarBase 6.0: capturing the exponential growth of miRNA targets with experimental support. Nucleic Acids Res 2012, 40:D222-229.

65. Hsu SD, Lin FM, Wu WY, Liang C, Huang WC, Chan WL, Tsai WT, Chen GZ, Lee CJ, Chiu CM, et al: miRTarBase: a database curates experimentally validated microRNA-target interactions. Nucleic Acids Res 2011, 39:D163-169.

66. Krek A, Grun D, Poy MN, Wolf R, Rosenberg L, Epstein EJ, MacMenamin P, da Piedade I, Gunsalus KC, Stoffel M, Rajewsky N: Combinatorial microRNA target predictions. Nat Genet 2005, 37:495500 .

67. Essaghir A, Toffalini F, Knoops L, Kallin A, van Helden J, Demoulin JB: Transcription factor regulation can be accurately predicted from the presence of target gene signatures in microarray gene expression data. Nucleic Acids Res 2010, 38:e120.

68. Zhao F, Xuan Z, Liu L, Zhang MQ: TRED: a Transcriptional Regulatory Element Database and a platform for in silico gene regulation studies. Nucleic Acids Res 2005, 33:D103-107.

69. Friard O, Re A, Taverna D, De Bortoli M, Cora D: CircuitsDB: a database of mixed microRNA/transcription factor feed-forward regulatory circuits in human and mouse. $B M C$ Bioinformatics 2010, 11:435.

70. Wingender E, Chen X, Hehl R, Karas H, Liebich I, Matys V, Meinhardt T, Pruss M, Reuter I, Schacherer F: TRANSFAC: an integrated system for gene expression regulation. Nucleic Acids Res 2000, 28:316-319.

71. Robinson PN, Mundlos S: The human phenotype ontology. Clin Genet 2010, 77:525-534.

72. Kuhn M, von Mering C, Campillos M, Jensen LJ, Bork P: STITCH: interaction networks of chemicals and proteins. Nucleic Acids Res 2008, 36:D684-688.

73. Smith CL, Eppig JT: The Mammalian Phenotype Ontology as a unifying standard for experimental and high-throughput phenotyping data. Mamm Genome 2012, 23:653-668.

74. Lim E, Pon A, Djoumbou Y, Knox C, Shrivastava S, Guo AC, Neveu V, Wishart DS: T3DB: a comprehensively annotated database of common toxins and their targets. Nucleic Acids Res 2010, 38:D781-786.

75. Schaefer CF, Anthony K, Krupa S, Buchoff J, Day M, Hannay T, Buetow KH: PID: the Pathway Interaction Database. Nucleic Acids Res 2009, 37:D674-679.

76. He X, Chang S, Zhang J, Zhao Q, Xiang H, Kusonmano K, Yang L, Sun ZS, Yang H, Wang J: MethyCancer: the database of human DNA methylation and cancer. Nucleic Acids Res 2008, 36:D836-841.

77. Lauss M, Visne I, Weinhaeusel A, Vierlinger K, Noehammer C, Kriegner A: MethCancerDB-aberrant DNA methylation in human cancer. Br J Cancer 2008, 98:816-817. 
bioRxiv preprint doi: https://doi.org/10.1101/082511; this version posted October 24, 2016. The copyright holder for this preprint (which was not certified by peer review) is the author/funder, who has granted bioRxiv a license to display the preprint in perpetuity. It is made available under aCC-BY-NC 4.0 International license.

Table 1. Sources for gene sets in GSKB.

\begin{tabular}{|c|c|c|c|c|}
\hline Type & Source & $\begin{array}{l}\text { \#Gene } \\
\text { sets }\end{array}$ & Reference & Note \\
\hline $\begin{array}{l}\text { Co- } \\
\text { expression }\end{array}$ & $\begin{array}{l}\text { Literature } \\
\text { MSigDB } \\
\text { L2L } \\
\text { CancerGenes* } \\
\text { GeneSigDB } \\
\end{array}$ & $\begin{array}{r}8747 \\
874 \\
248 \\
23 \\
310 \\
\end{array}$ & $\begin{array}{l}\text { Present } \\
{[5]} \\
{[44]} \\
{[45]} \\
{[46]} \\
\end{array}$ & $\begin{array}{l}\text { Differentially expressed genes from } 2526 \text { studies } \\
\text { Molecular Signature Database, v.3.1 } \\
\text { List of lists, v.2006.2 } \\
\text { Cancer gene lists } \\
\text { Gene Signature Database, R.4 } \\
\end{array}$ \\
\hline $\begin{array}{l}\text { Gene } \\
\text { Ontology }\end{array}$ & $\begin{array}{ll}\text { GO } & \mathrm{BP} \\
\mathrm{GO} & \mathrm{MF} \\
\mathrm{GO} & \mathrm{CC} \\
\end{array}$ & $\begin{array}{l}8203 \\
3240 \\
1082\end{array}$ & $\lceil 47\rceil$ & $\begin{array}{l}\text { Consistent descriptions of gene } \& \text { products } \\
\text { across species } \\
\text { v. } 201307\end{array}$ \\
\hline $\begin{array}{l}\text { Curated } \\
\text { pathways }\end{array}$ & $\begin{array}{l}\text { Biocarta } \\
\text { PANTHER } \\
\text { WikiPathways* } \\
\text { INOH* } \\
\text { NetPath* }\end{array}$ & $\begin{array}{r}176 \\
151 \\
146 \\
73 \\
25\end{array}$ & $\begin{array}{l}\text { Biocarta } \\
{[48]} \\
{[49]} \\
{[50]} \\
{[51]}\end{array}$ & $\begin{array}{l}\text { Metabolic and signaling pathways } \\
\text { Ontology-based pathway database, v3.3 } \\
\text { Open platform for pathway curation } \\
\text { Integrating network objects with hierarchies } \\
\text { Signal transduction pathways }\end{array}$ \\
\hline $\begin{array}{l}\text { Metabolic } \\
\text { pathways }\end{array}$ & $\begin{array}{l}\text { REACTOME } \\
\text { KEGG } \\
\text { EHMN* } \\
\text { MouseCyc }\end{array}$ & $\begin{array}{r}4243 \\
259 \\
53 \\
321 \\
\end{array}$ & $\begin{array}{l}{[52]} \\
{[53]} \\
{[54]} \\
{[55]}\end{array}$ & $\begin{array}{l}\text { Peer-reviewed pathway database, v2013.7 } \\
\text { Metabolic pathways, R.67.0 } \\
\text { Edinburgh human metabolic network } \\
\text { Mouse Biochemical Pathways , v2013.7 }\end{array}$ \\
\hline $\begin{array}{l}\text { Drug } \\
\text { related }\end{array}$ & $\begin{array}{l}\text { CTD* } \\
\text { SIDER* }\end{array}$ & $\begin{array}{l}910 \\
460\end{array}$ & {$[56]$} & $\begin{array}{l}\text { The Comparative Toxicogenomics Database } \\
\text { Side Effect Resource } \\
\text { Manually Annotated Targets and Drugs Online }\end{array}$ \\
\hline & MATADOR* & 248 & [58] & Resource \\
\hline & $\begin{array}{l}\text { DrugBank* } \\
\text { SMPDB* }\end{array}$ & $\begin{array}{r}136 \\
74 \\
\end{array}$ & $\begin{array}{l}{[59]} \\
{[60]}\end{array}$ & $\begin{array}{l}\text { Open data drug and target database } \\
\text { Small Molecule Pathway Database }\end{array}$ \\
\hline $\begin{array}{l}\text { miRNA } \\
\text { Target } \\
\text { Genes }\end{array}$ & $\begin{array}{l}\text { miRDB } \\
\text { microRNA.org } \\
\text { Grimson et al. } \\
\text { TarBase } \\
\text { miRTarBase* } \\
\text { MicroCosm* } \\
\text { PicTar }\end{array}$ & $\begin{array}{r}1157 \\
314 \\
179 \\
84 \\
54 \\
45 \\
35\end{array}$ & $\begin{array}{l}{[61]} \\
{[62]} \\
{[63]} \\
{[64]} \\
{[65]} \\
\text { ebi.ac.uk } \\
{[66]}\end{array}$ & $\begin{array}{l}\text { miRNA target prediction and annotations, } v 4.0 \\
\text { Predicted miRNA targets, v.R2010 } \\
\text { Predicted miRNA targets. v. } 6.2 \\
\text { Experimentally validated miRNA targets, v. } 6.0 \\
\text { Experimentally validated miRNA targets } \\
\text { Predicted targets } \\
\text { Predicted miRNA sites, v. } 2007.3\end{array}$ \\
\hline $\begin{array}{l}\text { TF Target } \\
\text { Genes }\end{array}$ & $\begin{array}{l}\text { TFactS } \\
\text { TRED } \\
\text { CircuitsDB } \\
\text { TRANSFAC }\end{array}$ & $\begin{array}{r}101 \\
99 \\
94 \\
78 \\
\end{array}$ & $\begin{array}{l}{[67]} \\
{[68]} \\
{[69]} \\
{[70]}\end{array}$ & $\begin{array}{l}\text { Predicted TF targets, v. } 2012.2 \\
\text { Confirmed TF target genes, v. } 2013.7 \\
\text { Mixed miRNA/TF regulation, v. } 2012 \\
\text { Confirmed TF binding sites, v7.0 }\end{array}$ \\
\hline Others & $\begin{array}{l}\text { Location } \\
\text { HPO* } \\
\text { STITCH* } \\
\text { MPO* } \\
\text { T3DB* } \\
\text { PID* } \\
\text { MethyCancer* } \\
\text { MethCancerDB* }\end{array}$ & $\begin{array}{r}392 \\
1518 \\
3929 \\
2943 \\
722 \\
193 \\
50 \\
19 \\
\end{array}$ & $\begin{array}{l}\text { BioMart } \\
{[71]} \\
{[72]} \\
{[73]} \\
{[74]} \\
{[75]} \\
{[76]} \\
{[77]} \\
\end{array}$ & $\begin{array}{l}\text { Genomic location on chromosomes, v. } 2013 \\
\text { The human phenotype ontology } \\
\text { Interaction networks of chemicals and proteins } \\
\text { Mammalian Phenotype Ontology } \\
\text { Database of common toxins and their targets } \\
\text { Pathway Interaction Database } \\
\text { Human DNA methylation and cancer } \\
\text { Aberrant DNA methylation in human cancer }\end{array}$ \\
\hline
\end{tabular}

* Secondary data downloaded from GeneSetDB [10].

** Databases were downloaded in July 2013. 
bioRxiv preprint doi: https://doi.org/10.1101/082511; this version posted October 24,2016 . The copyright holder for this preprint (which was not certified by peer review) is the author/funder, who has granted bioRxiv a license to display the preprint in perpetuity. It is made available under aCC-BY-NC 4.0 International license.

Table 2. Top 10 most frequent genes in 8,747 published lists of differentially expressed genes.

\begin{tabular}{|l|l|l|l|}
\hline $\begin{array}{l}\text { Freq- } \\
\text { uency }\end{array}$ & $\begin{array}{l}\text { Gene } \\
\text { Symbol }\end{array}$ & Official Full Name & $\begin{array}{l}\text { \#PubMed } \\
\text { Citations }\end{array}$ \\
\hline 615 & CDKN1A & $\begin{array}{l}\text { cyclin-dependent kinase inhibitor } \\
\text { 1A (P21) }\end{array}$ & 660 \\
\hline 498 & CCND2 & cyclin D2 & 239 \\
\hline 496 & MT1 & metallothionein 1 & 272 \\
\hline 493 & SOCS3 & suppressor of cytokine signaling 3 & 262 \\
\hline 490 & ID2 & inhibitor of DNA binding 2 & 256 \\
\hline 477 & EGR1 & early growth response 1 & 332 \\
\hline 465 & IGF1 & insulin-like growth factor 1 & 668 \\
\hline 463 & GJA1 & $\begin{array}{l}\text { gap junction protein, alpha } \\
\text { 1provided }\end{array}$ & 602 \\
\hline 457 & SCD1 & stearoyl-Coenzyme A desaturase 1 & 156 \\
\hline 454 & FOS & FBJ osteosarcoma oncogene & 440 \\
\hline
\end{tabular}


bioRxiv preprint doi: https://doi.org/10.1101/082511; this version posted October 24, 2016. The copyright holder for this preprint (which was not certified by peer review) is the author/funder, who has granted bioRxiv a license to display the preprint in perpetuity. It is made available under aCC-BY-NC 4.0 International license.

Table 3. Significant gene sets from pathway analysis using GSEA. ES: Enrichment Score, NES: Normalized Enrichment Score, P-val: Nominal P values, FDR: False discovery rate, FWER: family-wise error rate.

\begin{tabular}{lrccccc}
\hline NAME & SIZE & ES & NES & P-val & FDR & FWER \\
\hline MIRNA_MM_WANG_MMU-MIR-29C-3P & 220 & 0.604 & 1.722 & 0 & 0.013 & 0 \\
MIRNA_MM_WANG_MMU-MIR-29A-3P & 217 & 0.608 & 1.715 & 0 & 0.013 & 0.013 \\
MIRNA_MM_WANG_MMU-MIR-29B-3P & 221 & 0.591 & 1.711 & 0 & 0.013 & 0.013 \\
MIRNA_MM_WANG_MMU-MIR-767 & 112 & 0.558 & 1.559 & 0 & 0.099 & 0.262 \\
MIRNA_MM_WANG_MMU-MIR-5620-5P & 25 & 0.657 & 1.528 & 0.028 & 0.171 & 0.392 \\
MIRNA_MM_WANG_MMU-MIR-3065-3P & 192 & 0.431 & 1.519 & 0 & 0.163 & 0.428 \\
MIRTARBASE_MM_HSA-MIR-29B & 27 & 0.805 & 1.507 & 0.025 & 0.162 & 0.458 \\
MIRTARBASE_MM_HSA-MIR-29A & 21 & 0.763 & 1.503 & 0 & 0.158 & 0.472 \\
MIRNA_MM_GRIMSON_MIR-486-5P & 121 & 0.426 & 1.457 & 0 & 0.308 & 0.701 \\
MIRTARBASE_MM_HSA-MIR-29C & 20 & 0.894 & 1.449 & 0.034 & 0.312 & 0.737 \\
\hline
\end{tabular}


Table 4. Top gene sets in all categories from PGSEA analysis of the anti-miR-29 treated liver cells.

\begin{tabular}{|c|c|c|}
\hline Top Gene Sets by category & Pval & $\begin{array}{l}\text { Diff. in T } \\
\text { statistics }\end{array}$ \\
\hline \multicolumn{3}{|l|}{ Co-Expression } \\
\hline Wang_Rosiglitazone_Adipocyte-Secreted-Protein_Diff & 8.30E-04 & 14.9 \\
\hline Holl_Tcfap2C_Liver_Dn & $2.12 \mathrm{E}-04$ & -15.6 \\
\hline Nones_Mdr1A_Curcumin-Diet_Fibrogeneis_Dn & 2.44E-04 & 15.4 \\
\hline Burke_Transcriptional-Profile_Liver-Only_Dn & $2.78 \mathrm{E}-04$ & -15.2 \\
\hline Rampon_Pcdh12_Placenta_Cell-Matrix-Adhesion_Migration_Diff & 4.83E-04 & 13.6 \\
\hline \multicolumn{3}{|l|}{ Gene Ontology } \\
\hline Extracellular_Matrix_Structural_Constituent & $2.22 \mathrm{E}-04$ & 18.9 \\
\hline Collagen_Fibril_Organization & 7.30E-04 & 12.9 \\
\hline Cellular_Response_To_Amino_Acid_Stimulus & 4.62E-04 & 12.1 \\
\hline Glutathione_Transferase_Activity & $5.26 \mathrm{E}-04$ & -11.1 \\
\hline Basement_Membrane & $9.15 \mathrm{E}-04$ & 9.3 \\
\hline \multicolumn{3}{|l|}{ Metabolic Pathways } \\
\hline Cd44_Pathway & 3.11E-04 & 16.9 \\
\hline Ecm-Receptor_Interaction & 4.00E-04 & 11.4 \\
\hline Protein_Digestion_And_Absorption & $1.11 \mathrm{E}-04$ & 10.9 \\
\hline Cav1_Pathway & 5.73E-04 & 9.1 \\
\hline Glutathione_Metabolism & 4.51E-05 & -9.2 \\
\hline \multicolumn{3}{|l|}{ Mirna Target Genes } \\
\hline Hsa-Mir-29C & $1.45 \mathrm{E}-04$ & 17.3 \\
\hline Wang_Mmu-Mir-29C-3P & 5.19E-05 & 15.2 \\
\hline Wang_Mmu-Mir-29A-3P & $7.38 \mathrm{E}-05$ & 15.0 \\
\hline Grimson_Mir-29Abcd & 3.91E-05 & 15.6 \\
\hline Wang_Mmu-Mir-29B-3P & 7.32E-05 & 14.8 \\
\hline \multicolumn{3}{|l|}{ Currated Pathways } \\
\hline Integrin & $2.59 \mathrm{E}-04$ & 8.4 \\
\hline Pyruvate_Metabolism & $9.66 \mathrm{E}-04$ & -4.9 \\
\hline \multicolumn{3}{|l|}{ Transcription Factor Target Genes } \\
\hline Srebf1 & 4.62E-04 & -7.9 \\
\hline Smad3 & 4.01E-04 & 7.1 \\
\hline \multicolumn{3}{|l|}{ Other gene sets } \\
\hline Beta1_Integrin_Cell_Surface_Interactions & 2.77E-04 & 13.7 \\
\hline Mitral_Valve_Prolapse & $9.29 \mathrm{E}-04$ & 11.8 \\
\hline Abnormality_Of_The_Mitral_Valve & 8.73E-04 & 11.8 \\
\hline Syndecan-1-Mediated_Signaling_Events & $5.21 \mathrm{E}-04$ & 11.6 \\
\hline Osteoarthritis & 8.89E-04 & 11.0 \\
\hline
\end{tabular}


bioRxiv preprint doi: https://doi.org/10.1101/082511; this version posted October 24, 2016. The copyright holder for this preprint (which was not certified by peer review) is the author/funder, who has granted bioRxiv a license to display the preprint in perpetuity. It is made available under aCC-BY-NC 4.0 International license.

Table 5. Genes frequently appeared in gene set cluster A. Genes in bold are related to inflammatory response. Freq.: frequency, the number of gene sets with the gene.

\begin{tabular}{cll}
\hline Freq. & Symbol & Gene Name \\
\hline 5 & GFAP & glial fibrillary acidic protein \\
5 & OSMR & oncostatin M receptor \\
5 & TUBB6 & tubulin, beta 6 \\
4 & ANTX2 & anthrax toxin receptor 2 \\
4 & C1QC & complement component 1, q subcomponent, C chain \\
4 & CCL3 & chemokine (C-C motif) ligand 3 \\
4 & LY86 & lymphocyte antigen 86 \\
3 & C1QB & complement component 1, q subcomponent, beta \\
& & polypeptide \\
3 & C4B & similar to Complement C4 precursor \\
3 & CCL12 & chemokine (C-C motif) ligand 12 \\
3 & SERPINA3N & serine (or cysteine) peptidase inhibitor, clade A, 3N \\
3 & STAT3 & signal transducer and activator of transcription 3 \\
3 & B2M & beta-2 microglobulin \\
3 & BST2 & bone marrow stromal cell antigen 2 \\
3 & CD68 & CD68 antigen \\
3 & CHI3L1 & chitinase 3-like 1 \\
3 & CMTM3 & CKLF-like MARVEL transmembrane domain containing 3 \\
3 & EDN2 & endothelin 2 \\
3 & EMCN & endomucin \\
3 & EMP1 & epithelial membrane protein 1 \\
3 & IFITM3 & interferon induced transmembrane protein 3 \\
3 & IGFBP3 & insulin-like growth factor binding protein 3 \\
3 & LCN2 & lipocalin 2 \\
3 & LRRC2 & leucine rich repeat containing 2 \\
3 & MT1 & metallothionein 1 \\
3 & SEC22C & SEC22 vesicle trafficking protein homolog C (S. cerevisiae) \\
3 & SOCS3 & suppressor of cytokine signaling 3 \\
3 & TNFRSF12A & tumor necrosis factor receptor superfamily, member 12a \\
3 & TYROBP & TYRO protein tyrosine kinase binding protein \\
\hline & &
\end{tabular}


Table 6. Genes frequently appeared in gene sets cluster B. Genes in bold are related to visual perception according to GO.

\begin{tabular}{|c|c|c|}
\hline Freq. & Symbol & Gene Name \\
\hline 8 & ARR3 & arrestin 3 , retinal \\
\hline 7 & OPN1SW & $\begin{array}{l}\text { opsin } 1 \text { (cone pigments), short-wave-sensitive (color } \\
\text { blindness, tritan) }\end{array}$ \\
\hline 6 & CNGA1 & cyclic nucleotide gated channel alpha 1 \\
\hline 6 & GNAT2 & guanine nucleotide binding protein, alpha transducing 2 \\
\hline 6 & PDE6B & $\begin{array}{l}\text { phosphodiesterase } 6 \mathrm{~B}, \mathrm{cGMP} \text {, rod receptor, beta } \\
\text { polypeptide }\end{array}$ \\
\hline 6 & PDE6H & phosphodiesterase $6 \mathrm{H}, \mathrm{cGMP}$-specific, cone, gamma \\
\hline 5 & GNAT1 & guanine nucleotide binding protein, alpha transducing 1 \\
\hline 5 & PDE6C & phosphodiesterase 6C, cGMP specific, cone, alpha prime \\
\hline 5 & RCVRN & recoverin \\
\hline 5 & GNB3 & guanine nucleotide binding protein (G protein), beta 3 \\
\hline 5 & EA2 & erythrocyte antigen 2 \\
\hline 4 & PDE6G & phosphodiesterase 6G, cGMP-specific, rod, gamma \\
\hline 4 & RPGRIP1 & retinitis pigmentosa GTPase regulator interacting protein 1 \\
\hline 4 & AQP1 & aquaporin 1 \\
\hline 4 & CRX & cone-rod homeobox containing gene \\
\hline 4 & GNGT2 & $\begin{array}{l}\text { guanine nucleotide binding protein ( } G \text { protein), gamma } \\
\text { transducing activity polypeptide } 2\end{array}$ \\
\hline 4 & NR2E3 & nuclear receptor subfamily 2 , group $E$, member 3 \\
\hline 3 & ABCA4 & ATP-binding cassette, sub-family A (ABC1), member 4 \\
\hline 3 & CNGA3 & cyclic nucleotide gated channel alpha 3 \\
\hline 3 & CNGB3 & cyclic nucleotide gated channel beta 3 \\
\hline 3 & GUCA1B & guanylate cyclase activator $1 \mathrm{~B}$ \\
\hline 3 & OPN1MW & $\begin{array}{l}\text { opsin } 1 \text { (cone pigments), medium-wave-sensitive (color } \\
\text { blindness, deutan) }\end{array}$ \\
\hline 3 & PDE6A & phosphodiesterase 6A, cGMP-specific, rod, alpha \\
\hline 3 & ROM1 & rod outer segment membrane protein 1 \\
\hline 3 & SLC24A1 & $\begin{array}{l}\text { solute carrier family } 24 \text { (sodium/potassium/calcium } \\
\text { exchanger), member } 1\end{array}$ \\
\hline 3 & CALB2 & calbindin 2 \\
\hline 3 & CRYBA1 & crystallin, beta A1 \\
\hline 3 & GAS7 & growth arrest specific 7 \\
\hline 3 & GLB1L3 & galactosidase, beta 1 like 3 \\
\hline 3 & GNGT1 & $\begin{array}{l}\text { guanine nucleotide binding protein (G protein), gamma } \\
\text { transducing activity polypeptide } 1\end{array}$ \\
\hline 3 & MEF2C & myocyte enhancer factor $2 \mathrm{C}$ \\
\hline 3 & NEFM & neurofilament, medium polypeptide \\
\hline 3 & NRL & neural retina leucine zipper gene \\
\hline 3 & NXNL2 & nucleoredoxin-like 2 \\
\hline 3 & PDGFRA & platelet derived growth factor receptor, alpha polypeptide \\
\hline 3 & PITPNM3 & PITPNM family member 3 \\
\hline 3 & SPC25 & $\begin{array}{l}\text { SPC25, NDC80 kinetochore complex component, homolog } \\
\text { (S. cerevisiae) }\end{array}$ \\
\hline 3 & TRPM1 & $\begin{array}{l}\text { transient receptor potential cation channel, subfamily M, } \\
\text { member } 1\end{array}$ \\
\hline
\end{tabular}


bioRxiv preprint doi: https://doi org/10.1101/082511 this version posted October 24,2016 . The copyright holder for this preprint (which was not certified by peer review) is the author/funder, who has granted bioRxiv a license to display the preprint in perpetuity. It is made available under aCC-BY-NC 4.0 International license.

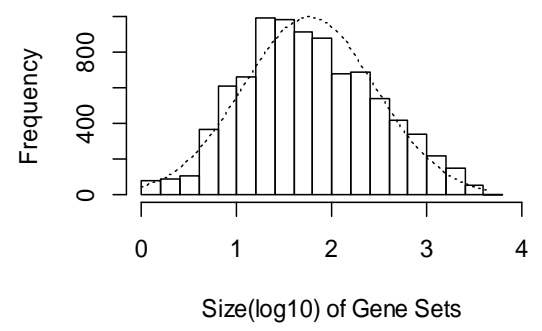

Fig. 1. Size distribution of the number of differentially expressed genes reported in the literature. 
bioRxiv preprint doi: https://doi.org/10.1101/082511; this version posted October 24,2016 . The copyright holder for this preprint (which was not certified by peer review) is the author/funder, who has granted bioRxiv a license to display the preprint in perpetuity. It is made available under aCC-BY-NC 4.0 International license.

\section{Anti-miR-29 Control P values}

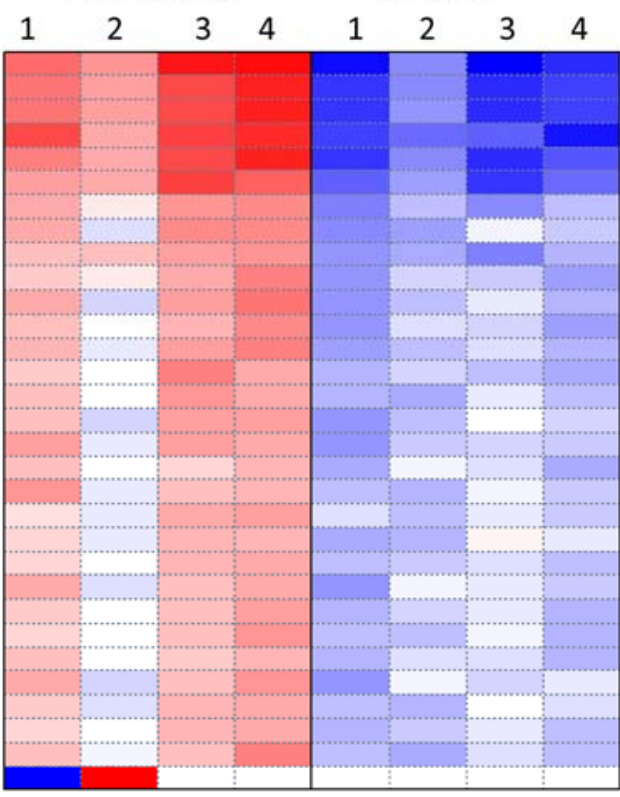

1e-04 HSA-MIR-29C

5e-05 WANG_MMU-MIR-29C-3P

$7 \mathrm{e}-05$ WANG_MMU-MIR-29A-3P

4e-05 GRIMSONN MIR-29ABCD

7e-05 WANG MMUU-MIR-29B-3P

1e-04 HSA-MIR-29B

4e-04 WANG MMU-MIR-767

1e-02 GRIMSŌN_MIR-101_101AB

2e-05 HSA-MIR-29A 1 -03 WANG MMU-MIR-3065-3P

2e-02 GRIMSŌN_MIR-144

4e-03 GRIMSON_MIR-300_381_539-3P

ee-03 GRIMSON_MIR-200B̄C_429_548A

3e-03 BETEL MMUU-MIR-770-5P

3e-03 GRIMSŌN MIR-25 32 92ABC 363_363-3P_367

3e-02 GRIMSON_MIR-26ÄB_1297_4465

7e-03 BETEL MM̄U-MIR-76̄

4e-03 GRIMSŌN_MIR-369-5P.B

1e-02 GRIMSON MIR-7 7AB

2e-02 KREK MMU-MIR-339-3P

4e-02 GRIMSON MIR-1843B-3P

4e-02 GRIMSON_MIR-1843B-3P

3e-03 WANG_MMU-MIR-32-5P
3e-02 WANG-MMU-MIR-7A-1-3P

3e-02 WANG_MMU-MIR-7A-1-3P

$5 e-03$ GRIMSŌN MIR-27ABC 27A-3P

3e-03 GRIMSON MIR-199AB-5P

4e-02 WANG MM̄U-MIR-467A-3P

4e-02 GRIMSŌN MIR-19AB

2e-03 WANG MMUU-MIR-363-3P

2e-03 WANG_MMU-MIR-363-3P

GS

Fig. 2. Significant gene sets from PGSEA analysis. Red indicates higher expression of genes targeted by certain microRNA according to prediction, while blue means lower expression. 
bioRxiv preprint doi: https://doi.org/10.1101/082511; this version posted October 24,2016 . The copyright holder for this preprint (which was not certified by peer review) is the author/funder, who has granted bioRxiv a license to display the preprint in perpetuity. It is made available under aCC-BY-NC 4.0 International license.

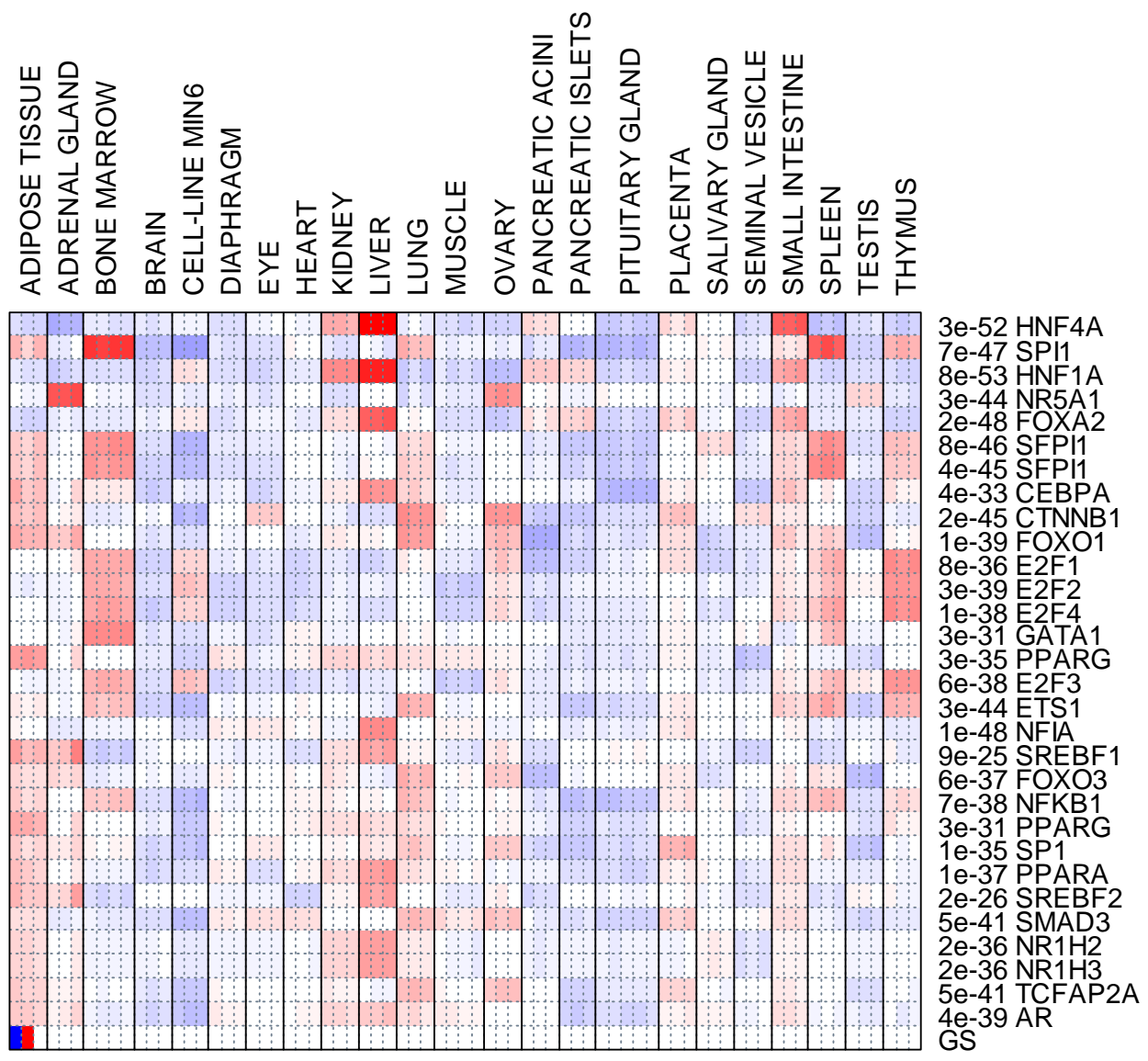

Fig.3. Significantly altered gene sets in normal tissues. Red represents higher expression of a set of genes regulated by a transcription factor. 


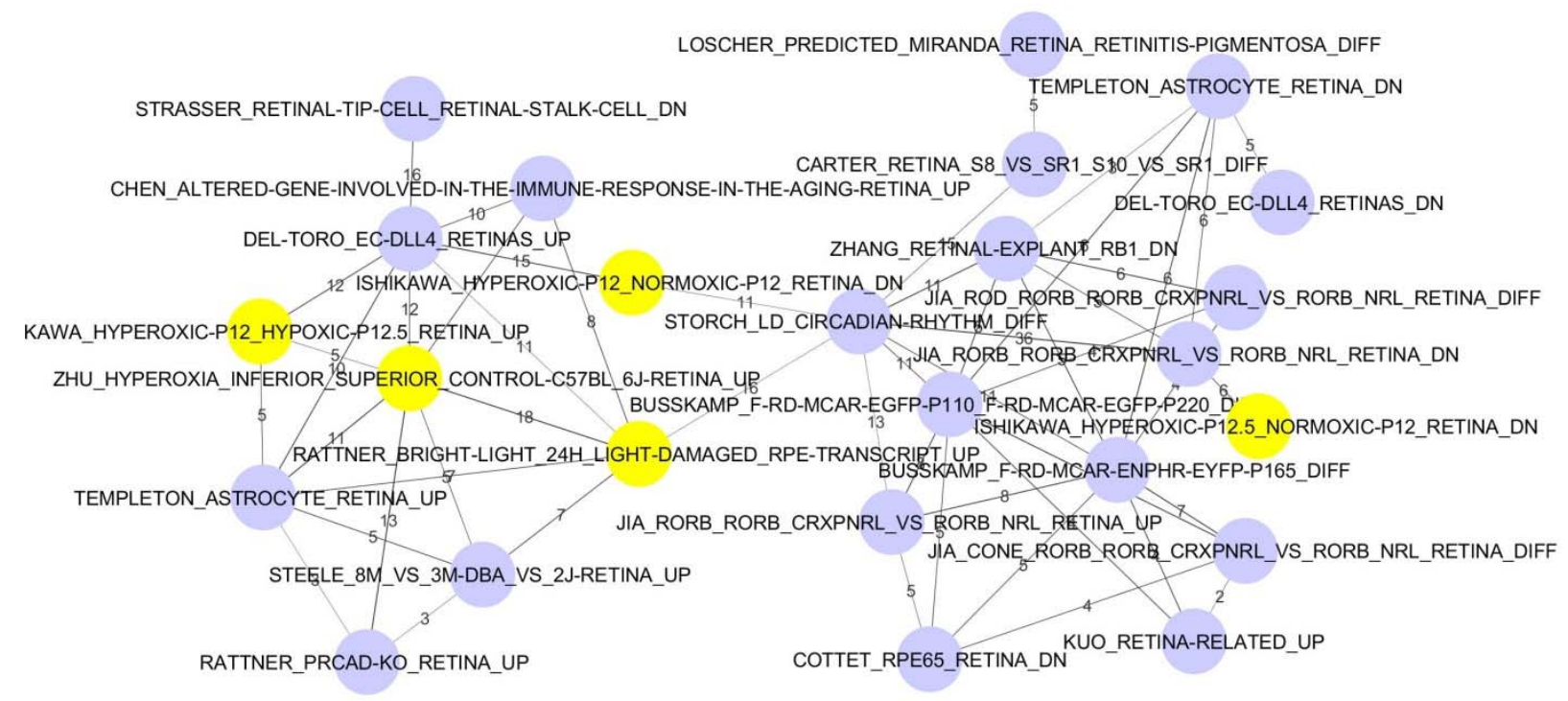

Fig. 4. Overlapping analysis of 46 published lists of differentially expressed genes related to the retina. Each note represents a gene list. Edges represent significant overlaps. Edge labels are the number of genes shared and the width indicates statistical significance. Highlighted in yellow are lists related to hypoxia. 